\title{
Psycho-Social Determinants of Street Beggars: A Comparative Study in Jordan
}

\author{
Ahmad Sa'ad Alsheikh Ali \\ Associate Professor, Psychology Department \\ The University of Jordan
}

\begin{abstract}
The issue of begging is now an all-pervasive manifestation and isn't a bizarre situation for any nation anymore. It is a social issue that prevails in the urban territories of the majority of countries. As the practice of begging is permeating through the society at a breakneck pace, an investigation into this psycho-social phenomenon is the need of the hour. In the view of the growing demand of research in this context, the present study explores the psycho-social factors that differentiate the beggars from non-beggars, i.e., the psycho-social factors that distinguish beggars from others aimed at identifying how the mindset of beggars differs from healthy individuals. Structured questionnaires were distributed to a sample of 117 beggars and 116 non-beggars to explore and understand how the psycho-social behavior of these individuals differ from each other. The idea is to be able to explain the reason why people beg and the real motive behind the existence of begging. This study identified various psycho-social characteristics that differentiate beggars from healthy individuals. It came to surface that impoverished family background, disrupted families, and poor financial status are the major factors that distinguish the beggars from the non-beggars. Also, the factors such as social conformity and decision making were found to be higher in healthy individuals than the beggars who could be attributed to a secure financial and family background, and various learning life experiences.
\end{abstract}

Keywords: Beggars, Begging, Education, Family, Psycho-Social Determinants, Street Begging, Unemployment, Poverty, Financial Status.

\section{Introduction}

Begging is not a regional issue; instead, it is a global problem that requires more attention. It could be observed that in the urban areas of every country in the world, begging is noticeable, making it an alarming urban issue. Although it is more pronounced in thirdworld countries, the problem of begging is a worldwide phenomenon. In metro cities of the world, it is evident that these cities have achieved enormous economic growth. This economic growth is visible through the structural and business growth in these metro cities. But on the hinder sight, there is a prevalence of beggars on the street in these metro cities. Begging is an activity that occurs in major cities and towns. Begging is a century old issue for major cities of the world.

Begging could have various meanings depending on the motive behind engagement with begging and the type of people who associate themselves with begging. Beggers have varying reasons for begging. Some beggars beg as fulfilling a ritual of either the family or the society, some begging as they consider it as their religious obligation whereas the majority of the beggars beg due to financial and economic constraints. The definition provided by MOLSA (1992) for begging is: "a method of earning one's living from the income obtained by others using age, health and economic condition as a means for gaining sympathy." Thus it is poverty that buds out to beg (Asrese, Tilahun, \& Mekonnen, 2014).

Beggars are the most deprive group of the society which compels them to opt for such a profession. Moreover, lack of access to the basic needs of life, which includes food, shelter, health, and protection, further instigate the beggars to cling to their profession. Hence, they are usually considered as the most unattended group of people who suffer from extreme negligence and poverty. Thus, to survive the unfavorable conditions these deprived poor people often resort into begging, a profession that involves no physical and mental effort, but still manages to provide the essentials that are required to meet the basic needs. Beggars undoubtedly survive on the sympathy of the people. Only handfuls are kind towards them. Globally, begging has been identified as a rising worldwide concern irrespective of whether developing or developed countries are taken into consideration. Reports have suggested that the 
population of beggars mostly include the aged people with poor health conditions, the physically challenged ones, and needy individuals suffering from mental sickness (Khan, 2013).

The problem of beggary, like any other social problem, is multidimensional. Its roots are found in the diverse patterns of its intertwined and interlocked social fabrics. A person is not likely to resort to beggary at the turn of a moment. Several factors act to recruit a person to this age-old profession. The current study aims to identify the psychological and social determinants that influence street beggars.

\section{Literature Review}

The population has risen to unmatched levels in the past few years. This has consequently affected the balance of basic needs that are required by every individual to survive. With the development of the economy, infrastructure, and public domains, the quality of life for human beings have somehow worsened over time (Kayed, 2018). The poor beggars are the most susceptible and vulnerable category of people who fail to survive the competition to earn the basic needs and hence ratify to begging. Moreover, increased levels of unemployment and degrading socioeconomic status further fuels the issue of begging (Mansour, 2015).

Street beggars can experience many problems related to the activity they are involved in. Being the most disadvantaged and marginalized section of the society, they tend to be grasped by several psycho-social issues such as a sense of alienation, depression, dependency, shame, stigmatization, discrimination and other health-related problems such as sexual harassment (Lucas, 2007). The phenomenon of begging, although considered as a new one, finds its existence long back in the society of all nations. The only difference being the current rise in the number of beggars. This problem is further reinforced by the statistical figures, as reported in Jordan. The stats provided by Muhareb et al. (2018) for juvenile beggers in Arab countries and specifically in Jordan revealed that the number of young beggars arrested for begging increased from 2,097 in 2011-2012 to 3,896 in 2012-2013. The similar indicator of juvenile beggers' arrest in Jordan and the Arab world increased to 4,074 in 2015, whereas, in 2016, there were 6,223 young beggars arrested for begging.

Another study, conducted by Namwata et al. (2012), indicated that in Tanzania, there $74 \%$ of the street beggars who felt depressive and guilty about begging. According to the beggers interviewed and surveyed by Namwata et al. (2012), they beg as this is their destiny which can not wand off shortly, even few of these beggers claiming that this is their destiny to beg for the lifetime. In Dodoma, $60 \%$ beggars and Singida34\% beggars contended that they don't desire to engage themselves with begging. Thus, it is evident from these pieces of research, that begging most of the time is not the desire or habit, it is the choice given to the beggars by destiny.

Mohammed et al. (2008) identified begging as a social problem which, apart from having psychological consequences, also results in the development of several other issues as well. These include the development of inferiority complex among the beggars, family members, and their community. Moreover, the phenomenon of begging also negatively affects the social structure of the urban area. Studies expressed that growing unemployment and poverty among families were the leading causes that pushed children towards the curse of beggary.

Baiee (2011) reported that the most visible consequence of child begging is related to the vulnerability of their life and health due to permanent residence in the street. They are threatened continuously by injuries in road traffic, but also by violence. Not only begging, but children engaged in begging are also found to be involved in juvenile prostitution, abusive use of drugs and other recreational substances and committing crimes such as theft and robbery (Mahmood, 2018). In this sense, forcing children into begging and its byproducts is the extreme violation of child rights.

Stones (2013) identified several factors that drive people towards begging. The phenomenon of begging acts as a natural means for earning the daily livelihoods and hence attracts the poor community who has no alternative source of income. Begging involves quick cash income, and thus, it is more comfortable for the beggars to meet their survival needs. Instead of indulging in criminal activities beggars, therefore, prefer to 
resort into begging. The other determinants of begging, as indicated in the study, include mental illness, social exclusion, and homelessness (Nahhas, 2016).

Moreover, instances of deliberately opting for begging phenomenon are also noted as the individuals find themselves satisfied with their lifestyle. Chinnappa (2014) mentioned that in most of the cases recorded by the Karnataka Legislature Committee on Woman and Child Welfare, India, beggars who were recovered from the rehabilitation centers were found to suffer from mental illnesses and depression. The committee recruited for investigating the beggars of the rehab centers revealed a large number of potential drivers of begging phenomena such as laziness, lack of shelter, and diseases. Researches have attempted to bridge depression and to beg; however, a sufficient amount of quality research is still required to put forward a clear picture.

Adriaenssens and Hendrickx (2011) identified begging as one of the street-level informal activities that allow the beggars to yield money and meet their basic needs. However, Kennedy \& Fitzpatrick, (2001) focused on the dark and seldom discussed facts that are associated with begging. Beggars, in most cases, are looked upon with a significant amount of disgust, and the phenomenon of begging is the least attractive among all other informal activities to yield money. Still, it is highly disappointing and disheartening that beggars are compelled to do begging as there is no alternative earning options available to them (The Jordan Times, 2008). Studies have portrayed that societal negligence severely harms the self-esteem of the beggars.

Tucker (2012) suggested poverty as the prime determinant factor for Generalized Anxiety Disorder (GAD). She highlighted in her report a study, conducted at Princeton University, comprising of 4,898 participants. All the women and child of age three years were observed. Results affirmed that a higher risk of being diagnosed with GAD is associated with mother's who endure poverty. Moreover, social stigma and insecurity related to the future additionally make things worse. Since beggars also belong to the poor class, they encounter similar problems as well. Thus there lies a potentiality that beggars also suffer from anxiety, which may result in GAD.
Ahmadi (2010) conducted a study to understand the impact of begging on the beggers and their families. These impacts were gauged from the viewpoint of their influence on psychological and social factors. Ahmadi (2010) found that begging not only paves the way for influencing the psychology of the beggers and their family negatively but also results in causing inferiority complex among them. The phenomenon of begging is predicted to be a threat to the social structure of the urban areas if not given proper attention.

While conducting the study on understanding the reasons for begging, Demewozu (2005) asserted that the changes observed in the society due to urbanization had paved the way for several issues to emerge as catastrophic for the structure of the society. Among these issues, Demewozu (2005) affirmed that begging is the most significant issue. It is like a global epidemic which is spreading internationally as a profession. Beggars are now very frequently observed at every corner of an area with maximum density around public organizations and churches (Mattar, 2011).

A qualitative study by Reda (2011) reported that beggars are subjected to discrimination, and hence, they were outcasted from the mainstream society. Society members insult them by saying, "son of a beggar." This result the beggars occupy the lower social strata; they have limited social interaction and community participation. Discrimination has emerged to segregation of the beggars from ordinary life. Observations made by the researchers revealed that the depressing facial expressions of the people who gave alms made the beggars feel unwanted and disrespected. At the same time, the use of certain offensive words such as poor, cheater, nonsense, and other adjectives further lowered self-respect of the beggars (Sarayrah, 2004). Inequity with beggars is dehumanizing and results in the development of various psychological problems such as low selfesteem, less self-confidence, poor social relationship, and even self-defeating behaviors on the beggars.

Several theories were explored by Ogunkan and Fawole (2009) to understand the dilemma of street begging. While conducting their research, Ogunkan and Fawole (2009) found 
and revealed that there are numerous reasons behind people begging. First of all, poverty paves the way for people begging so that they could fulfill the needs of their family (Mahmood, 2018). Religion was also found to be significantly contributing to people begging for food and money. Other significant reasons found by Ogunkan and Fawole (2009) were disabilities, either fake or real, which causes people to fail to adopt any profession, and thus, they end up begging on the streets. Culture and natural disasters were also ranked highly by Ogunkan and Fawole (2009) to be contributing to street begging. But above all these reasons, people with an addiction to drug and the absence of means to fulfill the habit was identified as the primary contributor for people engaging into begging.

A study carried out in the settings of Kingdom of Saudi Arabia (KSA) by Miller (2010) revealed that the kingdom provides shelter to children who are beggars, and once they are gathered at the shelter, they are deported to their native countries. Once such facility was located in Jeddah, where the researcher found that around 6,000 juvenile beggars were deported to their native countries since its incorporation. The shelter home, operated by the Saudi Ministry of Social Welfare, expelled around 363 child beggars from KSA. The facility also contained 48 local child beggars. The most frequent cause of beggary that has been identified is the increasing proportions of the population by which workers displaced from the land and unable to find employment. However, apart from the others such as displaced worker, disabled individuals, the blind, the deaf-mutes also resort into begging.

The categories of begging were identified in the research work conducted by Burke (1999) and Horn and Cooke (2001). Burke (1999) revealed that passive begging is one in which the beggers adopts a point to sit and ask people for funds and donations with the help of a signboard. Horn and Cooke (2001) explained active begging is the category of begging, in which the beggar begs for donations and funds at multiple spots. Besides funds and donations, active beggers also seek food and shelter from the donors. The most prominent category of beggers identified by Burke (1999) and Horn and Cooke (2001) was the aggressive beggars. These type of beggars beg by threatening the donor or using harsh words and cursing the donors. Mansour et al.
(2015) revealed that passive beggers are the most successful beggars as their soft and careless behavior achieves donors' sympathy.

The main reasons for beggars to depend on this practice, as identified by Wubshet et al. (2005), were following the previously identified ones such as the physical inability to do work, age-related issues at older ages, unemployment and underemployment. However, occasional factors included begging for transportation, medical treatment and being robbed by thieves. Analysis by Khan et al. (2013) further identified poverty and unemployment as the main problems faced by the beggars. Thus it was again reinstated that poverty and unemployment are undoubtedly the critical drivers of the begging phenomenon. The study also highlighted the variety of issues that the beggars have to fight every day. Some of the problems include lack of electricity, sanitation, safe water, decent housing.

Moreover, beggars also suffer from various diseases and remain unattended. It is unfortunate that the picture is all the same in both rural and urban areas. Beggars who settled coming from rural origin suffered from housing and water problems. Estimations revealed that about $6 \%$ district beggars, $2 \%$ beggars from rural areas and $11 \%$ from urban areas have no essential amenities and thus suffer mostly to sustain life.

All the researches in this regard have led to an obvious conclusion of begging to be a hereditary practice which is passed on to the younger generations of the presently existing beggars. Thus, the ancestral practice of begging is the most crucial factor that acts as the building base for the expansion of the phenomenon of begging. Apart from the disability of the poor people to manage their risks, numerous other factors also limit the escape of beggars from poverty which includes poor nourishment and health conditions, lack of self-belief, lack of knowledge, distance from the society and its elements (Ogunkan \& Fawole, 2009). Thus the poor people are unable to break the continuous cycle of poverty that revolves around their life, resulting in begging to be a hereditary phenomenon. The study, therefore, aims to highlight the psychological determinants of begging. 


\section{Problem Statement}

The modernization of urban areas in the world has paved the way for enormous growth in industries and has caused significant changes in the social structure of the societies. Due to this development, inflations has increased, which has created a significant chunk of the population to engage in active and passive begging. Jordan is a country which has transformed economically, industrially, and socially over time. Therefore, the presence of beggars in the country is undeniable. In the past, disabled and financially weak people were taken care of by their families and relatives. This trend has changed as families are nor focusing more on now meeting the needs of their immediate families first. In this sense, begging has increased as people have limited access to resources, and inflation has also caused the necessities to move out of their reach. The basic and dominating profession of agriculture has also been affected due to drought and transformation of the economy, which is now more focused on industries. In the wake of such a scenario, begging is, and there is a considerable shift observed among the population of Jordan, which is now migrating to urban areas.

According to the findings of the study conducted by Muhareb et al. (2018), it was reported that in Jordan, the phenomenon of begging has reached to unmatched levels. Although several attempts have been made to control the number of beggars, no positive outcome has been observed. Instead, according to the reports by Ministry of Social Development, about $79 \%$ of the country's street beggars are recorded in Amman with 2,945 beggars seized in 2018 as compared to 1,116 in 2015 and 400 during the same period in 2014.

There has been a lot of criticism received by beggers begging due to the social, cultural, and economic perspective shift. Still, there is a need for studying the problem of begging and what is its impact on the families in asking and on the society as a whole is inevitable. The studies carried out on begging and its effects on society and the lives of the beggers, but there is a gap in literature observed concerning begging's impact on the psychological and social determinants of the begging families.
Aim

The study aims to determine the psycho-social determinants of street beggars.

\section{Objectives}

The objectives of the study include-

1. To analyze the psycho-social differences between normal and street beggars.

2. To assess the influence of the demographic variables such as family status, education, gender, in collective begging.

\section{Research Questions}

1. What are the differences related to psychosocial characteristics between normal and street beggars?

2. What is the impact of psycho-social and demographic factors on the beggars?

3. What are the common psycho-social predictors of the street beggars?

\section{Hypotheses}

Hypothesis 1: Unemployment and unbalanced economic growth are the major factors influencing begging.

Hypothesis 2: Educational level of the beggers directly influences the means of personal income of the beggers.

Hypothesis 3: The level of education that the beggers possess directly influences their decision to send their children to educational institutes.

Hypothesis 4: The income of the beggars in a family is not significantly indicative of the monthly household income.

Hypothesis 5: Beggers' income is directly influenced by their physical or psychological disability.

\section{Methodology}

In this section of the report, the researcher has presented the method adopted to answer the research question and validate or reject the hypothesis set out in the previous section.

\section{Study Procedure}

\section{Research Approach}

The reasoning approach adopted in this study is the deductive approach. The study is based on establishing results to outline the psychosocial factors underlying the differences 
between the beggars and non-beggars through a quantitative analysis using the primary data gathered by administering a self-structured questionnaire. The results of this study are outcome oriented. Moreover, the research follows a pre-established set of variables and hypotheses (refer to the previous section) being tested, reflecting the assumption of a top-down approach (Vogt, 2011). Therefore, the research confirms all the requirements of being a deductive study.

\section{Research Design}

The purpose of this study is to identify the psycho-social factors that distinguish beggars from non-beggars. Hence, the research design adopted in this study is an exploratory research design as the research is based on a set of hypotheses that are required to be tested and deals with the "how" aspect of the probe, i.e., how are the beggars different from the normal individuals in terms of their psychosocial behavior. Further, in general terms, the research design adopted for this study is the Quantitative research design as the study is based on the analysis of the collected data by statistical means (McBurney \& White, 2013).

\section{Sampling}

The sampling procedure used for this study was the convenience sampling as the sample was taken as available from the centers who are related to the Ministry of social development in Jordan (May, 2011). An example of both beggars and non-beggars was selected for the study. A delinquent scale developed by Huizinga \& Esbensen (1991) was applied to the chosen sample of non-beggars to exclude those who exhibited any degree of negligent behavior in this sample. It was done to avoid the overlapping of responses of such individuals with the individuals in the example of beggars. As a result, 24 individuals were excluded from the selected sample arriving at a total sample size of 117 individuals for the non-beggars. For consistency in comparison, an attempt was made to ensure the inclusion of near about the same number of individuals for the sample of beggars. Hence, an example of 116 individuals was formed for the beggars.

\section{Study Tools}

As the research is based on a self-constructed survey instrument, the reliability of the survey instrument was assessed through Cronbach's
Alpha (a) (Fowler, 2014). The device was found to be sufficiently reliable. A comprehensive discussion of the same follows:

\section{Reliability Statistics}

To proceed for the factor analysis, the reliability of the research instrument (questionnaire) was tested using Cronbach's Alpha (a). The TCU Psychosocial Functioning and Motivation Scales developed by Kevin, Holcom and Simpson (1994) was used to collect data from both the set of respondents, i.e., beggars and non-beggars. The reliability of the scale consisting of the responses from the non-beggars was found to be 0.8 . Similarly, the authenticity of the range consisting of the responses from the beggars was found to be 0.905. An internal consistency value (Cronbach's $a \geq 0.70$ ) for newly developed scales has been recommended (Nie et al., 2013). A 0.7 reliability is considered sufficient for a survey instrument (Bland \& Altman, 1997), whereas some researchers believe 0.6 and higher as sufficient (Field, 2000). Hence, the internal consistency of the scale measuring responses from both the sample groups was found to be adequate, which reflects that the research instrument reliably measures the psycho-social behavior of the individuals in both the samples (Cooper \& Schindler, 2014).

\section{Correlation and Hypothesis Testing}

The discussed variables were made to undergo a variety of statistical tests such as descriptive statistics, t-test, ANOVA, regression analysis, correlation Analysis, chisquare test and factor analysis to investigate the association between the chosen variables. Factor analysis was used to reduce a large number of variables (59 items) to a small amount of factors for the ease of prediction of results. Further, the degree and strength of the relationship between the chosen variables were analyzed using the correlation and regression estimates. Hypotheses were tested using chi-square test, t-test, and ANOVA. All experiments were performed using the SPSS software (May, 2011). The results of this study pointed towards the establishment of various associations between the constructs which have been discussed comprehensively in the upcoming sections.

\section{Ethical Considerations}

The researcher has ensured that the ethical framework for carrying out ethical research is 
compiled to complete this report. The data collected for this research and its presentation is focused on compliance issues provided by the university. Therefore the researcher has avoided each aspect which might prove to be violating the university rules and procedures. The researcher has adequately referenced and cited all the external information, retrieved from past pieces of literature in a similar context. The researcher has ensured that the work presented in this report is free from plagiarism; however, the researcher has kept the plagiarism ratio within limits prescribed by the university. Moreover, the researcher has ensured that this report does not contain any misleading information which might influence the objectivity of the findings presented in it. The survey administered was non-interventional, responding to the questionnaire had been willful, informed consent was obtained from all the respondents, and all answers were fully deidentified to maintain confidentiality.

\section{Results}

\section{Factor Analysis}

An analysis using the Principal component method of extraction was employed to identify the number of factors to use. As per the Kaiser criterion, the components having the first eigenvalue of more than 1 are to be used as accepted factors. Out of the total 59 items, the initial eigenvalues of only 18 elements were found to be more than 1; hence, only 18 components were extracted as the factors to be used for the non-beggars. The Unrotated Factor Loadings and Communalities suggest that the elements other than the 18 components selected represent a tiny portion of variability, and hence, it is improbable that these factors could be significant. Further, for the beggars, out of the total 59 items, 14 such components were extracted. Using the rotated factor loadings, the results have been interpreted as under:

\section{For Non-beggars}

The reduced factors that were identified were linked to the extent of hostility exhibited by them, their planning behavior, anxiety and depression levels, importance of learned values, reliability, impulsive behavior, dependence over others, individual selfesteem, being drawn to easy things, childhood problems, exhaustion from routine life, social behavior and self-worth.

\section{For Beggars}

The reduced factors that were identified were linked to the extent of hostility exhibited by them, social importance and self-worth, their planning behavior, values possessed, decision making confidence, individual self-esteem, assessing behavior, social dependence and need to support their family at an early age. The factors reduced here were used for further analysis.

\section{T-test and ANOVA}

Specific hypotheses were formulated which were tested using ANOVA and T-test. The following are the significant results obtained through these tests:

\section{Hypothesis 1}

Null hypothesis: Levels of psychological and social factors do not differ among beggars according to demographic variables.

Alternative hypothesis: Levels of
psychological and social factors differed
among beggars according to demographic
variables.

Age

- Based on the results obtained through ANOVA (See Appendix 1), the significance values of the psycho-social factors: levels of depression, anxiety, decision-making confidence, childhood problems, hostility, risk-taking were found to be less than 0.05 . This reflects that the demographic variable 'age' has a significant impact on the levels of depression, anxiety, decision-making confidence, childhood problems, hostility, and risk-taking in beggars.

- The psycho-social factors' conformity' and 'self-esteem' do not differ based on the age of a beggar as the significance value of these variables came out to be more than 0.05 .

\section{Gender}

- Based on the results obtained through ANOVA (See Appendix 2), the significance values of the psycho-social factors: decision making confidence, childhood problems, hostility, and risk-taking were found to be less than 0.05 . This reflects that the demographic variable 'gender' has 
a significant impact on the decision making confidence, childhood problems, hostility, and risk-taking in beggars.

- The psycho-social factors' depression', 'anxiety,' 'conformity' and 'self-esteem' do not differ based on the gender of a beggar as the significance value of these variables came out to be more than 0.05 .

\section{Educational Qualifications}

- Based on the results obtained through ANOVA (See Appendix 3), the significance values of all the psycho-social factors considered in this study, i.e., self-esteem, depression, anxiety, decision making confidence, childhood problems, hostility, risk-taking, and social conformity were found to be more than 0.05 . Hence, none of the psycho-social variables differ based on the educational qualifications of a beggar.

\section{Financial Status}

- Based on the results obtained through ANOVA (See Appendix 4), the significance values of the psycho-social factors: depression and risk-taking were found to be less than 0.05 . This reflects that the demographic variable' financial status' has a significant impact on the depression and risk-taking in beggars.

- The psycho-social factors anxiety, decision-making confidence, childhood problems, hostility, and conformity do not differ based on the financial status of a beggar as the significance value of these variables came out to be more than 0.05 .

\section{Family Status}

- Based on the results obtained through ANOVA (See Appendix 5), the significance values of the psycho-social factors: depression, anxiety, decision-making confidence, childhood problems, hostility, and risk-taking were found to be less than 0.05. This reflects that the demographic variable' family status' has a significant impact on depression, anxiety, decisionmaking confidence, childhood problems, hostility, and risk-taking in beggars.

- The psycho-social factors' self-esteem' and 'conformity' do not differ based on the family status of a beggar as the significance value of these variables came out to be more than 0.05 .

Hence, it can be seen that the psycho-social variables differ based on most of the demographic variables (except only educational qualifications). Therefore, the alternative hypothesis has been accepted here, establishing that the levels of psychological and social factors differ among beggars according to demographic variables.

\section{Hypothesis 2}

Null hypothesis: There are no significant differences in psychological and social factors between beggars and non-beggars.

Alternative hypothesis: There are significant differences in psychological and social factors between beggars and non-beggars.

Based on the results of the paired t-test (see Appendix 6), all the psycho-social factors except risk-taking reported a level of significantly lower than 0.05 . This reflects that all the psycho-social variables except 'risktaking' differ in the beggars and non-beggars. Hence, the alternate hypothesis will be accepted here. Therefore, there are significant differences in psychological and social factors between the beggars and non-beggars.

\section{Regression Analysis}

\section{Hypothesis 3}

Null hypothesis: Levels of social factors do not have any impact on the psychological factors among beggars.

Alternative hypothesis: Levels of social factors have a significant impact on the psychological factors among beggars.

The correlation between the social and the psychological factors was recorded to be 0.622 (see Appendix 7), which indicates that there exists a moderate positive correlation between the variables under study. Further, the value of R-square was found to be 0.386 (see Appendix 7), which reflects that $38.6 \%$ of the variance in the psychological factors can be explained by the social factors. The significance value being less than 0.05 (see Appendix 7) also supports a high degree of correlation between social and psychological factors. Hence, the results favor the acceptance of the alternate hypothesis. Therefore, the levels of social factors have a significant 
impact on the psychological factors among beggars.

\section{Discussion}

The present study attempted to contribute to the existing literature by exploring the psychosocial factors that differentiate the beggars from non-beggars, i.e., the psycho-social factors that distinguish beggars from others aimed at identifying how the mindset of beggars differs from normal individuals. The idea is to study the state of mind of the beggars to be able to explain better the existence of begging. The study used questionnaires as an instrument for data collection to gather the views of different individuals in the said area. The significant constructs based on which such evaluation has been made were self-esteem, depression, anxiety, decision making confidence, childhood problems, hostility, and social conformity.

Where psycho-social factors were chosen to be the independent variables of this study, the act of begging had been the dependent variable. The idea had been to explore that how the psycho-social factors influencing an individual are responsible for a person choosing to beg, i.e., the extent to which the psycho-social mindset of an individual varies in beggars and non-beggars.

Correlation and regression analysis were undertaken to establish the interrelation and the strength of these relationships for all the variables and sub-variables under study. Concerning these two analyses, it was found that the levels of social factors have a significant impact on the psychological factors among beggars. Further, the factor analysis was undertaken to simplify the data and to characterize the correlations between the variables wherein multiple outcomes were expected. The factor analysis led to the identification of various factors based on which the psycho-social characteristics of the beggars can be differentiated from the nonbeggars. While many psycho-social characteristics were the same for both the groups (beggars and non-beggars), certain factors like social status, social importance, and self-worth were identified to be of vital importance for the non-beggars.

However, studies have also established [For example, see, Namwata et al. (2012)] that certain beggars assume begging to be just a normal economic activity where such individuals have reported that they were never despised or embarrassed by their friends or families for choosing to beg. There have been instances where the relatives or friends of beggars have borrowed money from them. This could be one of the reasons why social status or importance was not identified as an essential factor for the beggars as they have never been detected in their social circles for indulging into begging. On the other hand, factors like a high level of hostility and the need to support their families at an early age were identified for the beggars based on the factor loadings. Interestingly, self-esteem was found to be an essential factor for the beggars as well.

Further, the results of the t-test establish that there are significant differences in psychological and social factors between the beggars and non-beggars expect for risktaking. Risk-taking, as a psychological behavior, was seen to be the same in both groups. The beggars were found to be having significantly higher scores than the nonbeggars on self-esteem, depression, anxiety levels, childhood problems, and the degree of hostility. Deviant conduct such as thuggery (criminal and violent behavior), theft and vandalism are listed as some of the acts associated with street begging (Adedibu, 1989; Tambawal, 2010; Adedibu \& Jelili, 2011).

The beggars scored lower than the nonbeggars on only decision making confidence and conformity. These results could be attributed to the background of the individuals and the conditions under which these individuals were raised as decision making confidence and the willingness to abide by the social rules are heavily dependent on one's upbringing, and experiences as poverty are the most common precipitant of the act of begging. Hence, the results portray consistency with the statement by Lynch (2002), who stated that an individual's circumstances are responsible for the act of begging.

Further, other than these tests, the results based on ANOVA suggest that the psychosocial characteristics of the beggars and the non-beggars differ based on age, gender, financial status, and family status. However, these were not observed to vary based on the 
educational qualifications as opposed to the result of the study undertaken by Stones (2013) who established that homelessness and poor education were the major precipitating factors of the act of begging. However, it was also found in the same study that a disrupted family background also acts as a precipitating factor which is consistent with the results of this study. Therefore, it can also be said that owing to financial constraints and disrupted families, in the absence of any means of livelihood, people are driven to the practice of begging temporarily, and some permanently. Therefore, begging is done rarely by choice.

The inclination towards begging despite being educated could emerge from the fact that individuals can earn more from begging than they otherwise would. Cook (2010) presented that the beggars are so used to begging that they prefer not to work. Many of them also make more money from begging than they would if they did work. Namwata et al. (2012) recorded the same result in their study concerning family status. Poverty and unemployment were also identified as essential factors by them, supporting the result of this study that the financial situation also affects an individual's psycho-social behavior. Hence, disrupted families and poor economic status are the major factors that differentiate the beggars from the non-beggars.

\section{Conclusion}

Begging is often seen to be one of the most pressing social issues for any country. In light of this statement, the presented study attempted to explore the psycho-social factors that distinguish beggars from others aimed at identifying how the mindset of beggars differs from healthy individuals. Bearing in mind the context of the study, recapitulating the significant results, it can be stated that the individuals engage in the act of begging due to several psycho-social factors that are present in them in higher degrees as compared to the normal individuals. These factors range from higher self-esteem, depression, anxiety, and childhood problems to a high degree of hostility present in the beggars which may be attributed to a financial status that could not sufficiently equip the individuals to secure employment when needed. Also, impoverished family background and possible family disruptions could have led to the subsequent development of poor self-worth and negative social importance together with learned helplessness.

The factors such as social conformity and decision making were found to be higher in normal individuals than the beggars could be due to a strong financial and family background and various learning life experiences. Hence, the study identified various psycho-social characteristics that differentiate beggars from normal individuals. These factors can be used to determine the reasons why different individuals get accustomed to the practice of begging. Hence, this research can contribute to the discussions based on related ideas that may be utilized by anybody interested in the information on the mindset of the beggars. It can be primarily utilized by the government authorities to formulate policies, grants, and laws for such individuals indulging in the practice of begging for abstaining them from the act of begging to bring an end to this nuisance.

\section{References}

- Adriaenssens, S., \& Hendrickx, J. (2011). Street-level informal economic activities: estimating the yield of begging in Brussels. Urban Studies, 48(1), 23-40.

- Ahmadi, H. (2019). A study of beggars characteristics and attitude of people towards the phenomenon of begging in the city of Shiraz. Journal of Applied Sociology, 39(3), 135-148. Retrieved from http://ensani.ir/file/download/article/2 0120329160727-5081-26.pdf

- Al-Muhareb, T., \& Alzyoud, M. (2018). Begging Phenomenon in Jordan: Family Role and Causes.Modern Applied Science, 12(4), $57 . \quad$ doi: 10.5539/mas.v12n4p57

- Bland, J. M., \& Altman, D. G. (1997). Statistics notes: Cronbach's alpha. Bmj, 314(7080), 572.

- Burke, R. H. (1999). Tolerance or intolerance? The policing of begging in the urban context. Begging Questions: Streetlevel economic activity and social policy failure, $219 \mathrm{e} 235$.

- Cooper, D., \& Schindler, P. (2014). Business research methods. Boston: McGrawHill/Irwin.

- Ener, M. (1999). Prohibitions on begging and loitering in nineteenth-century Egypt. Die Welt des Islams, 39(3), 319-339. 
- Fawole, O. A., Ogunkan, D. V., \& Omoruan, A. (2011). The menace of begging in Nigerian cities: A sociological analysis. International Journal of sociology and AnthroPolog Y, 3(1), 9-14.

- Fowler, F. (2014). Survey research methods. London: Sage Publication.

- Horn, M., \& Cooke, M. (2001). A Question of Begging: A Study of the Extent and Nature of Begging in the City of Melbourne. Hanover Welfare Services.

- Kayed, M. (2018). Students at University of Jordan empathise with plight of child beggars on campus. Retrieved from http://www.jordantimes.com/news/loca 1/students-university-jordan-empathiseplight-child-beggars-campus

- Kennedy, C., \& Fitzpatrick, S. (2001). Begging, rough sleeping and social exclusion: Implications for social policy. Urban Studies, 38(11), 2001-2016.

- Lynch, P. (2002). Begging for change: Homelessness and the law. Melb. UL Rev., 26, 690.

- Mahmood, A. (2018). Giving children in street situations in Jordan hope for a brighter future. Retrieved from https://medium.com/@unicefjordan1/gi ving-street-children-in-jordan-hope-for-abrighter-future-d0e561d78a92

- Mansour, E. (2017). An explanatory study into the information seeking-behaviour of Egyptian beggars. Journal of Librarianship and Information Science, 49(1), 91-106.

- Mattar, M. Y. (2011). Human rights legislation in the Arab world: The case of human trafficking. Mich. J. Int'l L., 33, 101.

- May, T. (2011). Social research. Maidenhead: Open University Press.

- McBurney, D., \& White, T. (2013). Research methods. Belmont, CA: Wadsworth Cengage Learning.

- Miller, D. (2010). Child beggars not welcome in Saudi Arabia. Retrieved from https://www.jpost.com/Middle-

East/Child-beggars-not-welcome-inSaudi-Arabia

- Nahhas, R. (2016). Begging an alarming phenomenon in Jordan | Roufan Nahhas | AW. Retrieved from https://thearabweekly.com/beggingalarming-phenomenon-jordan
- Namwata, B., Mgabo, M., \& Dimoso, P. (2012). Categories of street beggars and factors influencing street begging in central Tanzania. African Study Monographs, 33(2), 133-143. Retrieved from https://repository.kulib.kyotou.ac.jp/dspace/bitstream/2433/158998/1 /ASM_33_133.pdf

- Nie, Y., Mao, X., Cui, H., He, S., Li, J., \& Zhang, M. (2013). Hospital survey on patient safety culture in China. BMC health services research, 13(1), 228.

- Ogunkan, D. V., \& Fawole, O. A. (2009). Incidence and socio-economic dimensions of begging in Nigerian cities: The case of Ogbomoso. International NGO Journal, 4(12), 498-503.

- Ogunkan, D. V., \& Jelili, M. O. (2010). The influence of land use on the spatial variation of begging in Ogbomoso, Nigeria. Journal of Geography and Regional Planning, 3(4), 73.

- Reda, T. (2011). The causes, prevalence and psycho-social consequences of begging in Addis Ababa among beggars coming from Tigray regional state (pp. 1-88). Addis Ababa: ADDIS ABABA UNIVERSITY. Retrieved from https://www.academia.edu/5006506/Th e_Causes_Prevalence_and_Psychosocial_ Consequences_of_Begging_in_Addis_Aba ba

- Sarayrah, Y. K. (2004). Servant leadership in the Bedouin-Arab culture. Global Virtue Ethics Review, 5(3-4), 58-80.

- Stones, C. R. (2013). A psycho-social exploration of street begging: A qualitative study. South African Journal of Psychology, 43(2), 157-166.

- Tambawal, M. U. (2010, June). The effects of street begging on the national development: counselling implications. In 1st National Conference of the Counselling Association of Nigeria (CASSON) Katsina State.

- The Jordan Times. (2008). Social Development Ministry to prepare new anti-begging plan. Retrieved from http://www.jordantimes.com/news/loca 1/social-development-ministry-preparenew-anti-begging-plan

- Tucker, N. (2012). Poverty May Be the Leading Cause of Generalized Anxiety Disorder, Not Mental Illness. Retrieved from 
https://www.medicaldaily.com/povertymay-be-leading-cause-generalizedanxiety-disorder-not-mental-illness-241457

- Vogt, W. (2011). SAGE Quantitative Research Methods. London: SAGE Publications.
- Woubishet, D. (2005). Begging as a means of livelihood: conferring with the poor at the orthodox religious ceremonial days in addis ababa. African study monographs. Supplementary issue, 29, pp-185. 
Appendix 1: ANOVA results for Age

\begin{tabular}{|c|c|c|c|c|c|c|}
\hline \multicolumn{7}{|c|}{ ANOVA } \\
\hline & & Sum of Squares & $\mathrm{df}$ & $\begin{array}{c}\text { Mean } \\
\text { Square }\end{array}$ & $\mathrm{F}$ & Sig. \\
\hline \multirow{3}{*}{ Self esteem } & Between Groups & .065 & 1 & .065 & .134 & .715 \\
\hline & Within Groups & 55.646 & 114 & .488 & & \\
\hline & Total & 55.711 & 115 & & & \\
\hline \multirow{3}{*}{ Depression } & Between Groups & 13.630 & 1 & 13.630 & 27.447 & .000 \\
\hline & Within Groups & 56.612 & 114 & .497 & & \\
\hline & Total & 70.242 & 115 & & & \\
\hline \multirow{3}{*}{ Anxiety } & Between Groups & 11.858 & 1 & 11.858 & 25.516 & .000 \\
\hline & Within Groups & 52.979 & 114 & .465 & & \\
\hline & Total & 64.837 & 115 & & & \\
\hline \multirow{3}{*}{$\begin{array}{l}\text { Decision } \\
\text { making } \\
\text { confidence }\end{array}$} & Between Groups & 2.322 & 1 & 2.322 & 4.176 & .043 \\
\hline & Within Groups & 63.388 & 114 & .556 & & \\
\hline & Total & 65.710 & 115 & & & \\
\hline \multirow{3}{*}{$\begin{array}{l}\text { Childhood } \\
\text { problems }\end{array}$} & Between Groups & 14.656 & 1 & 14.656 & 23.816 & .000 \\
\hline & Within Groups & 70.156 & 114 & .615 & & \\
\hline & Total & 84.812 & 115 & & & \\
\hline \multirow{3}{*}{ Hostility } & Between Groups & 39.890 & 1 & 39.890 & 38.219 & .000 \\
\hline & Within Groups & 118.985 & 114 & 1.044 & & \\
\hline & Total & 158.874 & 115 & & & \\
\hline \multirow{3}{*}{ Risk taking } & Between Groups & 2.441 & 1 & 2.441 & 7.918 & .006 \\
\hline & Within Groups & 35.145 & 114 & .308 & & \\
\hline & Total & 37.586 & 115 & & & \\
\hline \multirow{3}{*}{ Conformity } & Between Groups & 1.494 & 1 & 1.494 & 2.901 & .091 \\
\hline & Within Groups & 58.710 & 114 & .515 & & \\
\hline & Total & 60.204 & 115 & & & \\
\hline
\end{tabular}


Appendix 2: ANOVA results for Gender

\begin{tabular}{|c|c|c|c|c|c|c|}
\hline \multicolumn{7}{|c|}{ ANOVA } \\
\hline & & $\begin{array}{l}\text { Sum of } \\
\text { Squares }\end{array}$ & df & $\begin{array}{l}\text { Mean } \\
\text { Square }\end{array}$ & F & Sig. \\
\hline \multirow{3}{*}{ Self esteem } & Between Groups & .302 & 1 & .302 & .621 & .432 \\
\hline & Within Groups & 55.410 & 114 & .486 & & \\
\hline & Total & 55.711 & 115 & & & \\
\hline \multirow{3}{*}{ Depression } & Between Groups & .133 & 1 & .133 & .216 & .643 \\
\hline & Within Groups & 70.109 & 114 & .615 & & \\
\hline & Total & 70.242 & 115 & & & \\
\hline \multirow{3}{*}{ Anxiety } & Between Groups & .520 & 1 & .520 & .922 & .339 \\
\hline & Within Groups & 64.316 & 114 & .564 & & \\
\hline & Total & 64.837 & 115 & & & \\
\hline \multirow{3}{*}{$\begin{array}{l}\text { Decision making } \\
\text { confidence }\end{array}$} & Between Groups & 3.269 & 1 & 3.269 & 5.969 & .016 \\
\hline & Within Groups & 62.441 & 114 & .548 & & \\
\hline & Total & 65.710 & 115 & & & \\
\hline \multirow{3}{*}{$\begin{array}{l}\text { Childhood } \\
\text { problems }\end{array}$} & Between Groups & 9.850 & 1 & 9.850 & 14.979 & .000 \\
\hline & Within Groups & 74.962 & 114 & .658 & & \\
\hline & Total & 84.812 & 115 & & & \\
\hline \multirow{3}{*}{ Hostility } & Between Groups & 10.069 & 1 & 10.069 & 7.714 & .006 \\
\hline & Within Groups & 148.806 & 114 & 1.305 & & \\
\hline & Total & 158.874 & 115 & & & \\
\hline \multirow{3}{*}{ Risk taking } & Between Groups & 5.958 & 1 & 5.958 & 21.476 & .000 \\
\hline & Within Groups & 31.627 & 114 & .277 & & \\
\hline & Total & 37.586 & 115 & & & \\
\hline \multirow{3}{*}{ Conformity } & Between Groups & .683 & 1 & .683 & 1.308 & .255 \\
\hline & Within Groups & 59.521 & 114 & .522 & & \\
\hline & Total & 60.204 & 115 & & & \\
\hline
\end{tabular}


Appendix 3: ANOVA results for Educational Qualifications

\begin{tabular}{|c|c|c|c|c|c|c|}
\hline \multicolumn{7}{|c|}{ ANOVA } \\
\hline & & $\begin{array}{l}\text { Sum of } \\
\text { Squares }\end{array}$ & $\mathrm{df}$ & $\begin{array}{l}\text { Mean } \\
\text { Square }\end{array}$ & F & Sig. \\
\hline \multirow[t]{3}{*}{ Self esteem } & Between Groups & .277 & 1 & .277 & .571 & .452 \\
\hline & Within Groups & 55.434 & 114 & .486 & & \\
\hline & Total & 55.711 & 115 & & & \\
\hline \multirow[t]{3}{*}{ Depression } & Between Groups & .802 & 1 & .802 & 1.317 & .254 \\
\hline & Within Groups & 69.440 & 114 & .609 & & \\
\hline & Total & 70.242 & 115 & & & \\
\hline \multirow[t]{3}{*}{ Anxiety } & Between Groups & .010 & 1 & .010 & .018 & .893 \\
\hline & Within Groups & 64.826 & 114 & .569 & & \\
\hline & Total & 64.837 & 115 & & & \\
\hline \multirow{3}{*}{$\begin{array}{l}\text { Decision making } \\
\text { confidence }\end{array}$} & Between Groups & .205 & 1 & .205 & .356 & .552 \\
\hline & Within Groups & 65.505 & 114 & .575 & & \\
\hline & Total & 65.710 & 115 & & & \\
\hline \multirow[t]{3}{*}{ Childhood problems } & Between Groups & 1.305 & 1 & 1.305 & 1.781 & .185 \\
\hline & Within Groups & 83.507 & 114 & .733 & & \\
\hline & Total & 84.812 & 115 & & & \\
\hline \multirow[t]{3}{*}{ Hostility } & Between Groups & 4.592 & 1 & 4.592 & 3.393 & .068 \\
\hline & Within Groups & 154.282 & 114 & 1.353 & & \\
\hline & Total & 158.874 & 115 & & & \\
\hline \multirow[t]{3}{*}{ Risk taking } & Between Groups & .000 & 1 & .000 & .000 & .985 \\
\hline & Within Groups & 37.585 & 114 & .330 & & \\
\hline & Total & 37.586 & 115 & & & \\
\hline \multirow[t]{3}{*}{ Conformity } & Between Groups & .458 & 1 & .458 & .873 & .352 \\
\hline & Within Groups & 59.746 & 114 & .524 & & \\
\hline & Total & 60.204 & 115 & & & \\
\hline
\end{tabular}


Appendix 4: ANOVA results for Financial Status

\begin{tabular}{|c|c|c|c|c|c|c|}
\hline \multicolumn{7}{|c|}{ ANOVA } \\
\hline & & $\begin{array}{l}\text { Sum of } \\
\text { Squares }\end{array}$ & df & $\begin{array}{l}\text { Mean } \\
\text { Square }\end{array}$ & $\mathrm{F}$ & Sig. \\
\hline \multirow{3}{*}{ Self esteem } & Between Groups & 3.789 & 3 & 1.263 & 2.690 & .050 \\
\hline & Within Groups & 51.645 & 110 & .469 & & \\
\hline & Total & 55.434 & 113 & & & \\
\hline \multirow{3}{*}{ Depression } & Between Groups & 5.081 & 3 & 1.694 & 2.895 & .038 \\
\hline & Within Groups & 64.359 & 110 & .585 & & \\
\hline & Total & 69.440 & 113 & & & \\
\hline \multirow{3}{*}{ Anxiety } & Between Groups & 1.414 & 3 & .471 & .818 & .487 \\
\hline & Within Groups & 63.413 & 110 & .576 & & \\
\hline & Total & 64.826 & 113 & & & \\
\hline \multirow{3}{*}{$\begin{array}{l}\text { Decision } \\
\text { making } \\
\text { confidence }\end{array}$} & Between Groups & 1.345 & 3 & .448 & .768 & .514 \\
\hline & Within Groups & 64.161 & 110 & .583 & & \\
\hline & Total & 65.505 & 113 & & & \\
\hline \multirow{3}{*}{$\begin{array}{l}\text { Childhood } \\
\text { problems }\end{array}$} & Between Groups & 1.162 & 3 & .387 & .517 & .671 \\
\hline & Within Groups & 82.345 & 110 & .749 & & \\
\hline & Total & 83.507 & 113 & & & \\
\hline \multirow{3}{*}{ Hostility } & Between Groups & 4.041 & 3 & 1.347 & .986 & .402 \\
\hline & Within Groups & 150.241 & 110 & 1.366 & & \\
\hline & Total & 154.282 & 113 & & & \\
\hline \multirow{3}{*}{ Risk taking } & Between Groups & 5.282 & 3 & 1.761 & 5.996 & .001 \\
\hline & Within Groups & 32.303 & 110 & .294 & & \\
\hline & Total & 37.585 & 113 & & & \\
\hline \multirow{3}{*}{ Conformity } & Between Groups & .827 & 3 & .276 & .514 & .673 \\
\hline & Within Groups & 58.920 & 110 & .536 & & \\
\hline & Total & 59.746 & 113 & & & \\
\hline
\end{tabular}


Appendix 5: ANOVA results for Family Status

\begin{tabular}{|c|c|c|c|c|c|c|}
\hline \multicolumn{7}{|c|}{ ANOVA } \\
\hline & & $\begin{array}{l}\text { Sum of } \\
\text { Squares }\end{array}$ & df & $\begin{array}{l}\text { Mean } \\
\text { Square }\end{array}$ & $\mathrm{F}$ & Sig. \\
\hline \multirow[t]{3}{*}{ Self esteem } & Between Groups & 2.672 & 5 & .534 & .972 & .440 \\
\hline & Within Groups & 42.315 & 77 & .550 & & \\
\hline & Total & 44.987 & 82 & & & \\
\hline \multirow[t]{3}{*}{ Depression } & Between Groups & 6.953 & 5 & 1.391 & 3.256 & .010 \\
\hline & Within Groups & 32.888 & 77 & .427 & & \\
\hline & Total & 39.841 & 82 & & & \\
\hline \multirow[t]{3}{*}{ Anxiety } & Between Groups & 9.804 & 5 & 1.961 & 5.362 & .000 \\
\hline & Within Groups & 28.159 & 77 & .366 & & \\
\hline & Total & 37.964 & 82 & & & \\
\hline \multirow{3}{*}{$\begin{array}{l}\text { Decision } \\
\text { making } \\
\text { confidence }\end{array}$} & Between Groups & 9.502 & 5 & 1.900 & 4.454 & .001 \\
\hline & Within Groups & 32.853 & 77 & .427 & & \\
\hline & Total & 42.355 & 82 & & & \\
\hline \multirow{3}{*}{$\begin{array}{l}\text { Childhood } \\
\text { problems }\end{array}$} & Between Groups & 11.581 & 5 & 2.316 & 3.813 & .004 \\
\hline & Within Groups & 46.774 & 77 & .607 & & \\
\hline & Total & 58.355 & 82 & & & \\
\hline \multirow[t]{3}{*}{ Hostility } & Between Groups & 26.148 & 5 & 5.230 & 4.611 & .001 \\
\hline & Within Groups & 87.325 & 77 & 1.134 & & \\
\hline & Total & 113.473 & 82 & & & \\
\hline \multirow[t]{3}{*}{ Risk taking } & Between Groups & 7.426 & 5 & 1.485 & 5.058 & .000 \\
\hline & Within Groups & 22.611 & 77 & .294 & & \\
\hline & Total & 30.038 & 82 & & & \\
\hline \multirow[t]{3}{*}{ Conformity } & Between Groups & 2.821 & 5 & .564 & 1.101 & .367 \\
\hline & Within Groups & 39.464 & 77 & .513 & & \\
\hline & Total & 42.285 & 82 & & & \\
\hline
\end{tabular}


Appendix 6: Paired t-test based on the difference between beggars and non-beggars based on different psychosocial factors

\begin{tabular}{|c|c|c|c|c|c|}
\hline \multicolumn{6}{|c|}{ Paired Samples Statistics } \\
\hline & & Mean & $\mathrm{t}$ & $\mathrm{df}$ & Sig. (2-tailed) \\
\hline \multirow[t]{2}{*}{ Pair 1} & Self esteem & 3.4641 & \multirow[t]{2}{*}{4.936} & \multirow[t]{2}{*}{115} & \multirow[t]{2}{*}{0} \\
\hline & Self esteem - normal & 3.0603 & & & \\
\hline \multirow{2}{*}{ Pair 2} & Depression & 3.5388 & \multirow[t]{2}{*}{9.496} & \multirow[t]{2}{*}{115} & \multirow[t]{2}{*}{0} \\
\hline & Depression - normal & 2.5675 & & & \\
\hline \multirow{2}{*}{ Pair 3} & Anxiety & 3.2143 & \multirow[t]{2}{*}{6.334} & \multirow[t]{2}{*}{115} & \multirow[t]{2}{*}{0} \\
\hline & Anxiety - normal & 2.4933 & & & \\
\hline \multirow[t]{2}{*}{ Pair 4} & Decision making confidence & 3.0948 & \multirow[t]{2}{*}{-3.15} & \multirow[t]{2}{*}{115} & \multirow[t]{2}{*}{0.002} \\
\hline & $\begin{array}{c}\text { Decision making confidence - } \\
\text { normal }\end{array}$ & 3.4682 & & & \\
\hline \multirow[t]{2}{*}{ Pair 5} & Childhood problems & 3.4494 & \multirow[t]{2}{*}{9.313} & \multirow[t]{2}{*}{115} & \multirow[t]{2}{*}{0} \\
\hline & Childhood problems - normal & 2.5323 & & & \\
\hline \multirow[t]{2}{*}{ Pair 6} & Hostility & 3.4978 & \multirow[t]{2}{*}{9.354} & \multirow[t]{2}{*}{115} & \multirow[t]{2}{*}{0} \\
\hline & Hostility - normal & 2.2597 & & & \\
\hline \multirow[t]{2}{*}{ Pair 7} & Risk taking & 3.2783 & \multirow[t]{2}{*}{-0.12} & \multirow[t]{2}{*}{115} & \multirow[t]{2}{*}{0.904} \\
\hline & Risk taking - normal & 3.2894 & & & \\
\hline \multirow[t]{2}{*}{ Pair 8} & Conformity & 3.7241 & \multirow[t]{2}{*}{-2.706} & \multirow[t]{2}{*}{115} & \multirow[t]{2}{*}{0.008} \\
\hline & Conformity - normal & 3.9881 & & & \\
\hline
\end{tabular}

